\title{
Comparison of Personality Types and Learning Styles of Engineering Students, Agricultural Systems Management Students, and Faculty in an Agricultural and Biological EngineERIng DePartment
}

\author{
A. P. Zimmerman, R. G. Johnson, T. S. Hoover, J. W. Hilton, P. H. Heinemann, D. R. Buckmaster
}

\begin{abstract}
This study investigated differences in learning styles and personality types among engineering students, agricultural systems management students, and faculty in the Department of Agricultural and Biological Engineering at Pennsylvania State University. Learning styles and personality types were evaluated using the Group Embedded Figures Test $(G E F T)$ and Myers-Briggs Type Indicator (MBTI), respectively. Mean values for the GEFT for all three groups indicated a strong preference for the field-independent learning style. There were no significant differences in MBTI type preferences between engineering students and faculty. However, the agricultural systems management students differed significantly $(p<$ 0.05) from faculty in their preference for Perceiving and from engineering students in their preference for Sensing. Results of the study are useful in helping faculty better understand and improve the teaching and learning process involving the two groups of students.
\end{abstract}

Keywords. GEFT, Learning styles, MBTI, Personality type.

$\mathrm{T}$ he Department of Agricultural and Biological Engineering at Pennsylvania State University offers two majors: Agricultural and Biological Engineering (ABE), and Agricultural Systems Management (ASM). The ABE major is the professional engineering program and prepares students for careers in engineering. The ASM major prepares students for careers in agribusiness and integrates coursework in engineering technology, business management, and agricultural science. ABE and ASM departmental courses include similar subject matter and emphasize engineering principles and theory; however, there is less focus on engineering design and more emphasis on system analysis, functional planning, and applications in the ASM courses.

With few exceptions, departmental faculty teach both $\mathrm{ABE}$ and ASM courses. Most of these individuals have engineering degrees and have been educated in a culture dominated by engineering students and professors. However, they are now teaching courses to ASM students whose

Article was submitted for review in August 2005; approved for publication by the Education Division of ASABE in January 2006.

The authors are Allen P Zimmerman, ASABE Member Engineer, Professor, Agricultural Technical Institute, The Ohio State University, Wooster, Ohio; and Ronald G. Johnson, Instructor, College of Engineering and College of Business, Tracy S. Hoover, Associate Professor and Head, Department of Agricultural and Extension Education, James W. Hilton, ASABE Member, Associate Professor, Department of Agricultural and Biological Engineering, Paul H. Heinemann, ASABE Member Engineer, Professor, Department of Agricultural and Biological Engineering, and Dennis R. Buckmaster, ASABE Member Engineer, Associate Professor, Department of Agricultural and Biological Engineering, The Pennsylvania State University, University Park, Pennsylvania. Corresponding author: Paul H. Heinemann, 224 Agricultural Engineering Bldg., The Pennsylvania State University, University Park, PA 16802; phone: 814-865-2633; fax: 814-863-1031; e-mail: hzh@psu.edu. orientation to, and application of, engineering principles, practices, and analysis differ from that of $\mathrm{ABE}$ students. Faculty often observe (based on classroom performance, student comments, and course evaluations) that ASM majors typically have academic characteristics that differ from those of ABE students, yet many continue to teach ASM courses using engineering-oriented pedagogic methods.

The purpose of this study was to quantify the perceived differences in personality types and learning styles among ASM students, ABE students, and ABE faculty. The Myers-Briggs Type Indicator ${ }^{\circledR}$ (MBTI) ("Myers-Briggs Type Indicator" and "MBTI" are registered trademarks of Consulting Psychologists Press, Palo Alto, Cal.) and the Group Embedded Figures Test (GEFT) were used as the instruments to identify the personality types and learning styles of students and faculty. The MBTI and GEFT instruments were administered to ASM and ABE students and $\mathrm{ABE}$ faculty at the Pennsylvania State University. The results were then analyzed to determine if differences in personality types and learning styles exist between $\mathrm{ABE}$ and ASM students and between each of the student groups and the ABE faculty.

\section{A Brief OVERVIEW OF THE MBTI AND GEFT}

The MBTI is an instrument based on the work of Swiss psychiatrist Carl Jung and was developed over a 20-year period by Isabel Myers and Katherine Briggs (Myers et al., 1998; Provost and Anchors, 1987). Personality types are characterized by four pairs of preferences, which result in a total of 16 different personality type categories. The four pairs of preferences along with their letter designations and a brief description follow: (1) Extroversion versus Introver- 

sion (E or I), an indication of whether a person's primary energy source is external or internal; (2) Sensing versus Intuitive ( $\mathrm{S}$ or $\mathrm{N}$ ), an indication of the way a person prefers to receive information; (3) Thinking versus Feeling (T or F), an indication of the manner in which a person prefers to make decisions; and (4) Judging versus Perceiving ( $\mathrm{J}$ or P), an indication of a person's orientation to the outer world and preferred lifestyle.

Research has shown that personality type plays a role in a person's preferred learning and teaching style. A summary of type-related learning and teaching characteristics is provided in table 1 and is adapted from material presented by Lawrence (1997) and Myers et al. (1998). Personality type also plays an important role in people's career choices. For example, Kroeger et al. (2003) and Myers et al. (1998) listed and discussed occupational trends for the 16 MBTI types. Myers et al. (1998) did the same for the eight preference pairs and stated that the Sensing versus Intuition and Thinking versus Feeling pairs tend to have more impact on career selection than the other two sets of type preferences. Myers et al. (1998) used the following descriptors: Sensing ( $\mathrm{S}$, applied occupations), Intuition ( $\mathrm{N}$, theoretical occupations), Thinking ( $\mathrm{T}$, technical/scientific occupations), and Feeling (F, occupations emphasizing interpersonal aspects), which are of particular relevance to the populations in this study and suggest that MBTI types with an ST combination would be attracted to the ASM program and those with an NT combination would be attracted to the ABE program as both students and faculty.

Table 1. MBTI type-related learning and teaching characteristics. Adapted from material presented by Lawrence (1997) and Myers et al. (1998).

\section{Extroversion}

* Enjoy group activities

* Energized by people and environment

* Prefer a variety of tasks at the same time

* Spontaneous

* Tend to be action oriented

* Impatient to actively engage in a project

* Learning activities based on student input

* Attuned to attention levels of students

* Prefer movement and noise in classroom

\section{Sensing}

* Like assignments with precise directions

* Want material presented step-by-step

* Focused in the present

* Prefer sensual, application orientation

* Enjoy routine assignments and exercises

* Value experience and improving skills

* Emphasize facts and practical information

* Keep learning centralized

* Question for facts and predictable response

\section{Thinking}

* Value individual achievement

* Task oriented

* Need principles, ideas, and facts

* Find technology-oriented topics interesting

* Enjoy demonstrating competence

* Make few evaluative comments

* Use objective standards

* Prefer to attend to the class as a whole

\section{Judging}

* Prefer clearly-defined directions

* Enjoy the completion (results) of a project

* Need structure and predictability

* Organized and systematic

* Complete assignments well in advance

* Like to work on projects one at a time

* Prefer to set and adhere to fixed schedules

* Prefer quiet and orderly classrooms

* Class oriented and guided discussion
Introversion

Learning Styles

* Enjoy individual or one-on-one activities

* Energized by ideas

* Prefer concentrating on a few tasks at one time

* Think before discussing or deciding

* Tend to observe and reflect

* Must understand a project before attempting it

Teaching Styles

* Structured learning activities

* Attuned to topic being taught

* Prefer quiet and orderly classrooms

\section{Intuition}

Learning Styles

* Like assignments emphasizing creativity

* Want variety in the way material is presented

* Focused in the future

* Prefer principle and theory orientation

* Enjoy variety in assignments and exercises

* Value new ideas and learning new skills

Teaching Styles

* Emphasize concepts, relationships and implications

* Wide range of learning including small groups

* Question for synthesis and evaluation

Learning Styles

\section{Feeling}

* Value group achievement

* People oriented

* Need to know how people will be affected

* Find people-related topics interesting

* Enjoy pleasing people

Teaching Styles

* Regularly provide evaluative comments

* Use objective and subjective standards

* Prefer to attend to individual students

Learning Styles

Perceiving

* Prefer freedom and choices

* Enjoy the project activity more than the result

* Cope well with the unplanned and unexpected

* Spontaneous

* Complete assignments with a last-minute flurry

* Like to work on several projects simultaneously

Teaching Styles

* Prefer flexible schedules with student input

* Encourage movement and socializing in groups

* Promote independent and open-ended discussion 
The Group Embedded Figures Test (GEFT), developed by Witkin et al. (1971), classifies learners into two categories: field dependent and field independent. GEFT scores range from 0 to 18 with a national mean of 11.4 . Individuals scoring from 0 to 11 are classified as field dependent, and those from 12 to 18 are classified as field independent.

"Field dependent learners tend to be more social, have a more global perception, and learn more effectively in a non-formal environment. Field independent learners are better able to discern individual components and learn well in formalized settings" (Rudd et al., 1998, p. 18). Professors are more likely to teach in ways that facilitate students who share their learning style preference (Jacobson, 1992; Garger and Guild, 1984; Smith, 1982; Dunn and Dunn, 1979). A summary of the field dependent and field independent learning and teaching styles is provided in table 2 and is adapted from material presented by Garger and Guild (1984). Learning styles are also related to people's career choices. Witkin (1976) reported that field independent learners tend to be attracted to careers that required the use of their analytical skills, whereas field dependent learners prefer careers that require interpersonal skills. This suggests that field independent learners will predominate in all three of the study populations.

Two sets of the MBTI type preferences relate to mental functions (Sensing versus Intuition and Thinking versus Feeling) and have more to do with learning styles than the other two sets of type preferences (Introversion versus Extroversion, which relate to attitudes, and Judging versus Perceiving, which relate to orientation to the outer world) (Martin, 1997; Lawrence, 1997). Several authors have examined the relationship between the MBTI mental function preference pairs and the GEFT field dependent and field independent learning styles. Holsworth (1985), Corman and Platt (1988), and Canning (1983) reported some relationships between one or both of the MBTI mental function preference pairs and GEFT learning styles, whereas Lusk and Wright (1983) found no relationship between the two. Myers et al. (1998) list field dependent as a learning characteristic of Sensing oriented students and Feeling oriented students, and field independent as a learning characteristic of Intuitive oriented students and Thinking oriented students, based on their interpretation of the literature.
Only one study was found in the literature concerning differences between ABE and ASM students in terms of the MBTI. Barrett et al. (1987) evaluated the personality types of students in the College of Agriculture at the University of Nebraska - Lincoln. Although the statistical analysis was not applied specifically to differentiate between the agricultural mechanization (equivalent to ASM) and agricultural engineering (equivalent to $\mathrm{ABE}$ ) students, the data presented indicate a difference in the following MBTI type characteristics: E versus I - a much higher percentage of ASM students were $\mathrm{E}$ than were I when compared to the ABE students; $\mathrm{S}$ versus $\mathrm{N}$ - a much higher percentage of ASM students were $\mathrm{S}$ than were $\mathrm{N}$ when compared to the ABE students; and the SP subgroup (individuals with both $\mathrm{S}$ and $\mathrm{P}$ preferences) - a much higher percentage of the ASM students were in the SP subgroup than the ABE students.

Only one study was found in the literature concerning differences between faculty and students in an ABE type department in terms of the GEFT. Rudd et al. (1998) evaluated the learning style differences among students and faculty in the College of Agriculture at the University of Florida. However, the study grouped Agricultural Engineering (equivalent to $\mathrm{ABE}$ ) students and Agricultural Operations Management (equivalent to ASM) students together. Although the statistical analysis was not applied specifically to differentiate between these students and the faculty in the department, the data presented indicate a difference in learning styles in that the mean GEFT score for the students was 11.8 and that of faculty was 15.4 .

\section{Materials AND Methods}

\section{DATA ACQUISITION}

The MBTI and GEFT instruments were administered to sophomore, junior, and senior ABE and ASM students during spring semester, 2005. The MBTI instrument (Form M) was administered to the students in two ways. One of the authors of this article (Johnson) teaches two departmental courses titled "Leadership and Communications" (offered jointly and cross-listed as ASM/ABE 497A and 497B). Johnson is certified to administer and interpret the MBTI instrument and incorporates it as a regular part of these courses. In addition, ASM and ABE students in the sample population but not

Table 2. GEFT field dependent and field independent learning and teaching characteristics. Adapted from material presented by Garger and Guild (1984).

\begin{tabular}{lll}
\hline \multicolumn{1}{c}{ Field Dependent } & \multicolumn{1}{c}{ Field Independent } \\
\hline & Learning Styles & \\
* Perceive globally & & $*$ Perceive analytically \\
* Make broad concept distinctions & $*$ Make specific concept distinctions \\
* Demonstrate a social orientation & $*$ Demonstrate an impersonal orientation \\
* Prefer material relevant to own experience & $*$ Value new concepts for their own sake \\
* Require defined goals and reinforcement & $*$ Have self-designed goals and reinforcement \\
* Need organization to be provided & $*$ Can use self-structured situations \\
* More affected by criticism & $*$ Less affected by criticism \\
& & \\
* Prefer interaction and discussion & Teaching Styles & \\
* Use questions to evaluate student learning & & $*$ Prefer impersonal teaching methods \\
* Rely on student-centered activities & & $*$ Rely on teacher-oriented activities \\
*Viewed as teaching facts & & $*$ Viewed as teaching principles \\
* Provide less, but positive evaluations & $*$ Provide more, but negative evaluations \\
* Establish warm, personal environment & & $*$ Establish structured, guided environment \\
\hline
\end{tabular}


enrolled in Johnson's courses were invited to complete the MBTI instrument at a special evening session.

One of the authors (Hoover) has expertise in administering and interpreting the GEFT instrument. All ASM and ABE students in the sample population were invited to complete the GEFT instrument at a special evening session. A small incentive was provided to those students who completed both instruments.

Faculty data were also collected during spring semester, 2005. The MBTI and GEFT instruments were administered during two luncheon sessions after the faculty were given an orientation to the study.

\section{Statistical Analysis}

MBTI data were analyzed using the Selection Ratio Type Table (SRTT), a PC software program available from CAPT (Granade et al., 1987). SRTT determines the probability of differences in the distribution of the following (each referred to as a cell in the table produced as a result of the statistical analysis) for a sample population compared to a base population:

- The 16 MBTI types (ISTJ and ENTP are examples).

- The EI, SN, TF, and JP preference pairs.

- A number of subgroups based on any two of the preferences (ST and NJ are examples).

This program uses chi square (or Fisher's exact probability if cell frequencies are 5 or less) to determine if differences between values in the two populations are significant at the $\mathrm{p}<0.05, \mathrm{p}<0.01$, or $\mathrm{p}<0.001$ levels of confidence. The variable used to indicate differences in the two populations is the selection ratio. If the ratio is more than 1.00 , there is a greater observed frequency in that cell of the table than expected when compared to the base population. Likewise, if the ratio is less than 1.00 , there is a less observed frequency than expected.

The reliability and validity of the GEFT were established during the development of the instrument (Witkin et al., 1971). GEFT data were analyzed and interpreted using descriptive statistics. The findings are limited to those students and faculty who participated in the study.

\section{Results AND Discussion MBTI RESULTS}

The MBTI type compositions of the ABE student, ASM student, and ABE faculty populations are listed in table 3. As discussed previously, the SRTT statistical program was used for the comparison of the MBTI characteristics of the various populations. The SRTT output consists of a table of ratios calculated for: (1) the 16 MBTI types, (2) the EI, SN, TF, and JP preference pairs, and (3) a number of preference subgroups. The SRTT output also indicates if the ratio is statistically significant.

\section{ASM Students Compared to ABE Students}

The results of the comparison of the ASM student population to the ABE student population are shown in table 4. The results show that the ratios for the ESTP type (6.55), Sensing (1.64), and the subgroups ST (1.69) and SP (2.62) significant at the 0.05 level.

The results concerning the significantly higher index for the S preference and SP subgroup for ASM students are in agreement with those reported by Barrett et al. (1987) and
Table 3. MBTI results for the ABE student, ASM student, and ABE faculty populations.

\begin{tabular}{|c|c|c|c|c|c|c|}
\hline \multirow{2}{*}{$\begin{array}{l}\text { MBTI } \\
\text { Type[a] }\end{array}$} & \multicolumn{2}{|c|}{$\begin{array}{l}\text { ABE Students } \\
\quad(n=24)\end{array}$} & \multicolumn{2}{|c|}{$\begin{array}{l}\text { ASM Students } \\
\quad(n=22)\end{array}$} & \multicolumn{2}{|c|}{$\begin{array}{l}\text { ABE Faculty } \\
\quad(n=20)\end{array}$} \\
\hline & No. & $\%$ & No. & $\%$ & No. & $\%$ \\
\hline ISTJ & 2 & 8.3 & 2 & 9.1 & 4 & 20.0 \\
\hline ISFJ & 1 & 4.2 & 1 & 4.5 & 2 & 10.0 \\
\hline INFJ & 1 & 4.2 & 1 & 4.5 & 1 & 5.0 \\
\hline INTJ & 0 & 0.0 & 0 & 0.0 & 3 & 15.0 \\
\hline ISTP & 4 & 16.7 & 6 & 27.2 & 3 & 15.0 \\
\hline ISFP & 0 & 0.0 & 0 & 0.0 & 0 & 0.0 \\
\hline INFP & 5 & 20.8 & 1 & 4.5 & 1 & 5.0 \\
\hline INTP & 3 & 12.5 & 0 & 0.0 & 1 & 5.0 \\
\hline ESTP & 1 & 4.2 & 6 & 27.2 & 1 & 5.0 \\
\hline ESFP & 0 & 0.0 & 0 & 0.0 & 0 & 0.0 \\
\hline ENFP & 0 & 0.0 & 0 & 0.0 & 0 & 0.0 \\
\hline ENTP & 2 & 8.3 & 2 & 9.1 & 1 & 5.0 \\
\hline ESTJ & 4 & 16.7 & 3 & 13.6 & 2 & 10.0 \\
\hline ESFJ & 0 & 0.0 & 0 & 0.0 & 0 & 0.0 \\
\hline ENFJ & 1 & 4.2 & 0 & 0.0 & 0 & 0.0 \\
\hline ENTJ & 0 & 0.0 & 0 & 0.0 & 1 & 5.0 \\
\hline I & 16 & 67.7 & 11 & 50.0 & 15 & 80.0 \\
\hline E & 8 & 33.3 & 11 & 50.0 & 5 & 20.0 \\
\hline S & 12 & 50.0 & 18 & 81.8 & 12 & 60.0 \\
\hline $\mathrm{N}$ & 12 & 50.0 & 4 & 18.2 & 8 & 40.0 \\
\hline $\mathrm{T}$ & 16 & 66.7 & 19 & 86.4 & 16 & 80.0 \\
\hline $\mathrm{F}$ & 8 & 33.3 & 3 & 13.6 & 4 & 20.0 \\
\hline $\mathrm{J}$ & 9 & 37.5 & 7 & 31.8 & 13 & 65.0 \\
\hline $\mathrm{P}$ & 15 & 62.5 & 15 & 68.2 & 7 & 35.0 \\
\hline Female & 8 & 33.3 & 1 & 4.5 & 2 & 10.0 \\
\hline Male & 16 & 67.3 & 21 & 95.5 & 18 & 90.0 \\
\hline $\begin{array}{l}\mathrm{E}=\mathrm{E} \\
\mathrm{I}=\mathrm{In} t\end{array}$ & $\begin{array}{l}\text { versio } \\
\text { ersion }\end{array}$ & $\begin{array}{l}\mathrm{S}=\mathrm{S} \\
\mathrm{N}=\end{array}$ & & $\begin{array}{l}\text { Thinki } \\
\text { Feeling }\end{array}$ & $\begin{array}{l}\mathrm{J}=\mathrm{J} \\
\mathrm{P}=\mathrm{F}\end{array}$ & $\begin{array}{l}\text { ng } \\
\text { iving }\end{array}$ \\
\hline
\end{tabular}

discussed earlier. In addition, even though the index for $\mathrm{E}$ for the ASM students was not significant at the 0.05 level, its value of 1.50 is in agreement with the Barrett et al. (1987) results, indicating a much higher percentage ASM students preferring $\mathrm{E}$ as opposed to the $\mathrm{ABE}$ students. The results of this study and that of Barrett et al. (1987) show that ASM students are clearly different from ABE students in their information acquisition and energy source preferences.

Based on the characteristics summarized in table 1, it follows that the student population in the ASM program, which emphasizes practical applications of technical and business concepts to current situations, would attract a high percentage of Sensing and Extroversion types. Likewise, the professional engineering ABE program would more likely attract Intuitive and Introversion types. The high percentage of SPs in general and the ESTP type in particular in the ASM population also adheres to type theory. The preferred learning styles of SPs include such characteristics as "physical involvement and activity," "verbal and visual," "resourceful," and "immediacy (short attention span)." Terms used to describe the preferred learning style of ESTPs include "natural curiosity," "sensory-rich physical activities," "analytical and logical," "concrete experiences," and "in the present."

It should also be noted that a very high percentage (33.3\%) of ABE students are female, whereas there was only one female student in the ASM population. Gender differences have been documented in the Thinking (T) versus Feeling (F) MBTI preferences (Myers et al., 1998). Females are much 
Table 4. Comparison of the MBTI characteristics of the ASM student population $(n=22)$ to the ABE student population $(n=24)$.

\begin{tabular}{|c|c|c|c|c|c|c|c|c|}
\hline $\begin{array}{l}\text { MBTI } \\
\text { Type } e^{[a]}\end{array}$ & Ratio $^{[b]}$ & $\begin{array}{c}\text { Level of } \\
\text { Significance } \\
\text { [c] }\end{array}$ & $\begin{array}{c}\text { MBTI } \\
\text { Preference }\end{array}$ & Ratio & $\begin{array}{c}\text { Level of } \\
\text { Significance }\end{array}$ & $\begin{array}{c}\text { MBTI } \\
\text { Preference }\end{array}$ & Ratio & $\begin{array}{c}\text { Level of } \\
\text { Significance }\end{array}$ \\
\hline ISTJ & 1.09 & ns & E & 1.50 & ns & IJ & 1.09 & ns \\
\hline ISFJ & 1.09 & ns & I & 0.75 & ns & IP & 0.46 & $\mathrm{~ns}$ \\
\hline INFJ & 1.09 & ns & $S$ & 1.64 & $*$ & EP & 2.91 & ns \\
\hline INTJ & 0.00 & ns & $\mathrm{N}$ & 0.36 & $*$ & EJ & 0.65 & ns \\
\hline ISTP & 1.64 & $\mathrm{~ns}$ & $\mathrm{~T}$ & 1.30 & ns & ST & 1.69 & $*$ \\
\hline ISFP & 0.00 & $\mathrm{~ns}$ & $\mathrm{~F}$ & 0.41 & ns & SF & 1.09 & ns \\
\hline INFP & 0.22 & $\mathrm{~ns}$ & $\mathrm{~J}$ & 0.85 & ns & $\mathrm{NF}$ & 0.31 & ns \\
\hline INTP & 0.00 & $\mathrm{~ns}$ & $\mathrm{P}$ & 1.09 & $\mathrm{~ns}$ & NT & 0.44 & ns \\
\hline ESTP & 6.55 & $*$ & & & & SJ & 0.94 & ns \\
\hline ESFP & 0.00 & $\mathrm{~ns}$ & & & & SP & 2.62 & $*$ \\
\hline ENFP & 0.00 & $\mathrm{~ns}$ & & & & $\mathrm{NP}$ & 0.33 & $\mathrm{~ns}$ \\
\hline ENTP & 1.09 & $\mathrm{~ns}$ & & & & $\mathrm{NJ}$ & 0.55 & ns \\
\hline ESTJ & 0.82 & ns & & & & $\mathrm{TJ}$ & 0.91 & ns \\
\hline ESFJ & 0.00 & ns & & & & TP & 1.53 & ns \\
\hline ENFJ & 0.00 & ns & & & & FP & 0.22 & ns \\
\hline \multirow[t]{5}{*}{ ENTJ } & 0.00 & $\mathrm{~ns}$ & & & & FJ & 0.73 & ns \\
\hline & & & & & & IN & 0.24 & $*$ \\
\hline & & & & & & EN & 0.73 & ns \\
\hline & & & & & & IS & 1.40 & ns \\
\hline & & & & & & ES & 1.96 & ns \\
\hline
\end{tabular}

$\mathrm{I}=$ Introversion $\quad \mathrm{N}=$ Intuition $\quad \mathrm{F}=$ Feeling $\quad \mathrm{P}=$ Perceiving

[b] The ratio is calculated by dividing the sample population frequency value by the base population frequency value. For example, the index for ISTJ is 1.09 . This means that the percentage of ISTJs in the ASM student population (sample population) is 1.09 times the percentage in the ABE student population (base population). Data analyzed by chi square.

[c] $*=$ the ratio is significant at $\mathrm{p}<0.05 ; \mathrm{ns}=$ the ratio is not significant.

Table 5. Comparison of the ABE student population $(n=24)$ to the ABE faculty $(n=20)$.

\begin{tabular}{|c|c|c|c|c|c|c|c|c|}
\hline $\begin{array}{l}\text { MBTI } \\
\text { Type }{ }^{[a]}\end{array}$ & Ratio $^{[b]}$ & $\begin{array}{c}\text { Level of } \\
\text { Significance }[\mathrm{c}]\end{array}$ & $\begin{array}{c}\text { MBTI } \\
\text { Preference }\end{array}$ & Ratio & $\begin{array}{c}\text { Level of } \\
\text { Significance }\end{array}$ & $\begin{array}{c}\text { MBTI } \\
\text { Preference }\end{array}$ & Ratio & $\begin{array}{c}\text { Level of } \\
\text { Significance }\end{array}$ \\
\hline ISTJ & 0.42 & $\mathrm{~ns}$ & $\mathrm{E}$ & 1.33 & $\mathrm{~ns}$ & IJ & 0.33 & $*$ \\
\hline ISFJ & 0.42 & $\mathrm{~ns}$ & I & 0.89 & $\mathrm{~ns}$ & IP & 2.00 & $\mathrm{~ns}$ \\
\hline INFJ & 0.83 & ns & S & 0.83 & ns & EP & 1.25 & ns \\
\hline INTJ & 0.00 & ns & $\mathrm{N}$ & 1.25 & ns & EJ & 1.39 & ns \\
\hline ISTP & 1.11 & $\mathrm{~ns}$ & $\mathrm{~T}$ & 0.83 & $\mathrm{~ns}$ & ST & 0.92 & ns \\
\hline ISFP & 0.00 & $\mathrm{~ns}$ & $\mathrm{~F}$ & 1.67 & $\mathrm{~ns}$ & SF & 0.42 & ns \\
\hline INFP & 4.17 & $\mathrm{~ns}$ & $\mathrm{~J}$ & 0.58 & $\mathrm{~ns}$ & $\mathrm{NF}$ & 2.92 & $\mathrm{~ns}$ \\
\hline INTP & 2.50 & $\mathrm{~ns}$ & $\mathrm{P}$ & 1.79 & ns & NT & 0.69 & $\mathrm{~ns}$ \\
\hline ESTP & 0.83 & ns & & & & SJ & 0.73 & $\mathrm{~ns}$ \\
\hline ESFP & 0.00 & $\mathrm{~ns}$ & & & & SP & 104 & ns \\
\hline ENFP & 0.00 & ns & & & & NP & 2.78 & ns \\
\hline ENTP & 1.67 & $\mathrm{~ns}$ & & & & $\mathrm{NJ}$ & 033 & $\mathrm{~ns}$ \\
\hline ESTJ & 1.67 & ns & & & & $\mathrm{TJ}$ & 0.50 & ns \\
\hline ESFJ & 0.00 & $\mathrm{~ns}$ & & & & $\mathrm{TP}$ & 1.39 & $\mathrm{~ns}$ \\
\hline ENFJ & 0.00 & $\mathrm{~ns}$ & & & & FP & 4.17 & $\mathrm{~ns}$ \\
\hline \multirow[t]{5}{*}{ ENTJ } & 0.00 & $\mathrm{~ns}$ & & & & FJ & 0.83 & $\mathrm{~ns}$ \\
\hline & & & & & & IN & 1.25 & $\mathrm{~ns}$ \\
\hline & & & & & & EN & 1.25 & $\mathrm{~ns}$ \\
\hline & & & & & & IS & 0.65 & $\mathrm{~ns}$ \\
\hline & & & & & & ES & 1.39 & $\mathrm{~ns}$ \\
\hline
\end{tabular}

[a] $\mathrm{E}=$ Extroversion $\mathrm{S}=$ Sensing $\mathrm{T}=$ Thinking $\quad \mathrm{J}=$ Judging

$\mathrm{I}=$ Introversion $\quad \mathrm{N}=$ Intuition $\mathrm{F}=$ Feeling $\quad \mathrm{P}=$ Perceiving

[b] The ratio is calculated by dividing the sample population frequency value by the base population frequency value. For example, the index for ISTP is 1.11 . This means that the percentage of ISTPs in the ABE student (sample population) is 1.11 times the percentage in the ABE faculty population (base population). Data analyzed by chi square.

[c] $*=$ the ratio is significant at $\mathrm{p}<0.05$; $\mathrm{ns}=$ the ratio is not significant.

more likely to prefer $\mathrm{F}$ versus $\mathrm{T}$, and males vice versa. However, Myers et al. (1998) also state that for occupations such as engineering, which traditionally attract more Ts than Fs, a higher percentage of the women will show a preference for $\mathrm{T}$ than those in the general population. This may explain why the index for Thinking (1.30) indicates a higher percentage of Ts in the ASM student population compared to the ABE student population, but the difference is not significant. 
Table 6. Comparison of the ASM student population $(n=22)$ to the ABE faculty $(n=20)$.

\begin{tabular}{|c|c|c|c|c|c|c|c|c|}
\hline $\begin{array}{l}\text { MBTI } \\
\text { Type }^{[a]}\end{array}$ & $\operatorname{Ratio}^{[b]}$ & $\begin{array}{c}\text { Level of } \\
\text { Significance } \\
\text { [c] }\end{array}$ & $\begin{array}{c}\text { MBTI } \\
\text { Preference }\end{array}$ & Ratio & $\begin{array}{c}\text { Level of } \\
\text { Significance }\end{array}$ & $\begin{array}{c}\text { MBTI } \\
\text { Preference }\end{array}$ & Ratio & $\begin{array}{c}\text { Level of } \\
\text { Significance }\end{array}$ \\
\hline ISTJ & 0.45 & ns & E & 2.00 & ns & IJ & 0.36 & $*$ \\
\hline ISFJ & 0.45 & ns & I & 0.67 & ns & IP & 1.27 & ns \\
\hline INFJ & 0.91 & ns & $\mathrm{S}$ & 1.36 & ns & EP & 3.61 & ns \\
\hline INTJ & 0.00 & ns & $\mathrm{N}$ & 0.45 & ns & EJ & 0.91 & ns \\
\hline ISTP & 1.82 & $\mathrm{~ns}$ & $\mathrm{~T}$ & 1.08 & ns & ST & 1.55 & ns \\
\hline ISFP & 0.00 & $\mathrm{~ns}$ & $\mathrm{~F}$ & 0.68 & ns & SF & 0.45 & $\mathrm{~ns}$ \\
\hline INFP & 0.91 & $\mathrm{~ns}$ & $\mathrm{~J}$ & 0.49 & $*$ & $\mathrm{NF}$ & 0.91 & ns \\
\hline INTP & 0.00 & $\mathrm{~ns}$ & $\mathrm{P}$ & 1.95 & $*$ & NT & 0.30 & $\mathrm{~ns}$ \\
\hline ESTP & 5.45 & $\mathrm{~ns}$ & & & & SJ & 0.68 & $\mathrm{~ns}$ \\
\hline ESFP & 0.00 & ns & & & & SP & 2.73 & $*$ \\
\hline ENFP & 0.00 & ns & & & & NP & 0.91 & ns \\
\hline ENTP & 1.82 & $\mathrm{~ns}$ & & & & $\mathrm{NJ}$ & 0.18 & $\mathrm{~ns}$ \\
\hline ESTJ & 1.36 & $\mathrm{~ns}$ & & & & $\mathrm{TJ}$ & 0.45 & $\mathrm{~ns}$ \\
\hline ESFJ & 0.00 & $\mathrm{~ns}$ & & & & $\mathrm{TP}$ & 2.12 & $*$ \\
\hline ENFJ & 0.00 & $\mathrm{~ns}$ & & & & FP & 0.91 & ns \\
\hline \multirow[t]{5}{*}{ ENTJ } & 0.00 & $\mathrm{~ns}$ & & & & FJ & 0.61 & ns \\
\hline & & & & & & IN & 0.30 & $\mathrm{~ns}$ \\
\hline & & & & & & EN & 0.91 & ns \\
\hline & & & & & & IS & 0.91 & ns \\
\hline & & & & & & ES & 2.73 & ns \\
\hline
\end{tabular}

[a] $\mathrm{E}=$ Extroversion $\mathrm{S}=$ Sensing $\quad \mathrm{T}=$ Thinking $\quad \mathrm{J}=$ Judging

$\mathrm{I}=$ Introversion $\quad \mathrm{N}=$ Intuition $\mathrm{F}=$ Feeling $\quad \mathrm{P}=$ Perceiving

[b] The ratio is calculated by dividing the sample population frequency value by the base population frequency value. For example, the index for ISTP is 1.82 . This means that the percentage of ISTPs in the ASM student (sample population) is 1.82 times the percentage in the ABE faculty population (base population). Data analyzed by chi square.

[c] $*=$ the ratio is significant at $\mathrm{p}<0.05 ; \mathrm{ns}=$ the ratio is not significant.

\section{ASM and ABE Students Compared to ABE Faculty}

The results of the comparison of the ABE and ASM student populations to the ABE faculty population are shown in tables 5 and 6 . There were no significant differences in any of the MBTI type preferences for the ABE students versus faculty. The results for the ASM students show ratios for Perceiving (1.95) and three subgroups related to the JP pair (SP, 2.73; TP, 2.12; and IJ, 0.36) that were significant at the 0.05 level. Educational institutions operate in a Judging world, and Js predominate among the teaching population (Lawrence, 1997). Judging types tend to obtain higher grades than Perceiving types and make up increasingly higher percentages of the population as the education level increases (Myers et al., 1998). Therefore, it is helpful to the success of $\mathrm{P}$ students that teachers take into account such key P characteristics as "preference for choices and spontaneity," "enjoyment of project activity," and "last-minute flurry to complete assignments" when structuring course activities and assignments.

The low sample numbers in all three populations limit the ability to effectively interpret the results. However, it is interesting to observe that for the two sets of type preferences that relate to mental functions (Sensing versus Intuition, and Thinking versus Feeling), the ratios are reversed for the two populations of students when compared to the faculty, whereas this is not true for the other two sets of type preferences (Introversion versus Extroversion, which relate to attitudes, and Judging versus Perceiving, which relate to orientation to the outer world).

\section{GEFT RESULTS}

The GEFT mean scores are listed in table 7. The values for ABE students (16.5), ASM students (14.6), and ABE faculty (15.7) indicate that the majority of all three populations prefer a field independent style of learning. The GEFT mean score for the ABE faculty is close to the mean score (15.4) reported by Rudd et al. (1998) for the Agricultural Engineering faculty in the University of Florida study. The mean scores for the ABE and ASM students range higher than the combined mean score (11.8) reported for the University of Florida Agricultural Engineering and Agricultural Operations Management students by Rudd et al. (1998). Overall, the mean GEFT scores for student and faculty groups in the two studies are similar and reflect a preference for the field independent learning style.

\section{Conclusions}

Mean values for the GEFT for all three groups in the study indicate a strong preference for the field independent learning style. There were no significant differences in MBTI type preferences between ABE students and faculty. However, the ASM students differed significantly from faculty in their preference for Perceiving, and engineering students differed significantly from faculty in their preference for Sensing. Implicit in the MBTI results for the ASM students

Table 7. GEFT results for the ABE student, ASM student, and ABE faculty populations.

\begin{tabular}{lcccccccc}
\hline & \multicolumn{2}{c}{$\begin{array}{c}\text { ABE Students } \\
(n=22)\end{array}$} & & \multicolumn{2}{c}{$\begin{array}{c}\text { ASM Students } \\
(n=17)\end{array}$} & & \multicolumn{2}{c}{$\begin{array}{c}\text { ABE Faculty } \\
(n=21)\end{array}$} \\
\cline { 2 - 3 } & No. & $\%$ & & No. & $\%$ & & No. & $\%$ \\
\hline Field dependent & 1 & 4.5 & & 3 & 17.6 & & 3 & 14.3 \\
Field independent & 21 & 95.5 & & 14 & 82.4 & & 18 & 85.7 \\
\hline Female & 8 & 36.4 & & 0 & 0.0 & & 1 & 4.8 \\
Male & 14 & 63.6 & & 17 & 100.00 & & 20 & 95.2 \\
\hline Mean GEFT score & 16.5 & & & 14.6 & & & 15.7 & \\
\hline
\end{tabular}


is the importance of applied laboratory settings, current and practical problem situations, and self-selected group projects in the teaching and learning process. In general, the results of this study concur with learning style and personality type theory and with the results of previous studies reported in the literature.

Perhaps the most important outcome of this study is that it provides an opportunity for $\mathrm{ABE}$ faculty to learn more about the teaching and learning process and to reflect on their own teaching styles and practices. One concrete example is that the study has served as the basis for a follow-up teaching improvement workshop held for ABE faculty. Results of the study are also useful in helping faculty better understand and improve the teaching and learning process for ABE and ASM students.

This study was limited to students and faculty at only one department, and the results may not be representative of populations at similar departments in other colleges. In addition, the sample populations were small, which precluded detailed analysis of such items as the effect of the relatively high percentage of females in the ABE population, differences in the populations of students choosing the biological engineering versus agricultural engineering option, and the higher than expected percentage of students with a preference for $\mathrm{P}$ in the ABE population. Therefore, additional studies involving the personality type and learning style profiles of students and faculty in college departments similar to $\mathrm{ABE}$ are recommended.

\section{REFERENCES}

Barrett, L., R. Sorensen, and T. Hartung. 1987. Personality types of agricultural college students: Implications for teaching, retention, and recruitment. NACTA J. 31(4): 14-19.

Canning, E. 1983. An analysis of cognitive style, hemispheric preference, personality type, and academic achievement in a group of economically disadvantaged secondary students. $\mathrm{PhD}$ diss. Pittsburgh, Pa.: University of Pittsburgh.

Corman, L., and R. Platt. 1988. Correlations among the Group Embedded Figures Test, the Myers-Briggs Type Indicator, and demographic characteristics: A business school study. Perceptual and Motor Skills 66(2): 507-511.
Dunn, R., and K. Dunn. 1979. Learning styles/teaching styles: Should they...can they be matched? Educational Leadership 36(4): 238-244.

Kroeger, O., J. Thuesen, and. H. Rutledge. 2003. The Work Profiles. New York, N.Y.: Bantam Doubleday Bell.

Garger, S., and P. Guild. 1984. Learning styles: The critical difference. Curriculum Review 23(1): 9-12.

Granade, J., H. Hatfield, S. Smith, and J. Beasley. 1987. Selection Ratio Type Table PC program. Gainesville, Fla.: Center for Applications of Psychological Type.

Holsworth, T. 1985. Perceptual style correlates for the MBTI. J. Psychological Type 10: 32-35.

Jacobson, R. 1992. Research on differing ways of being smart leads to six-year project on teaching and learning "practical intelligence" in schools. The Chronicle of Higher Education Oct. 21. Available at: http://chronicle.com/.

Lawrence, G. 1997. Looking at Type and Learning Styles. Gainesville, Fla.: Center for Applications of Psychological Type.

Lusk, E., and H. Wright 1983. Relation of scores on Group Embedded Figures Test and Myers-Briggs Type Indicator. Perceptual and Motor Skills 57(3): 1209-1210.

Martin, C. 1997. Looking at Type: The Fundamentals. Gainesville, Fla.: Center for Applications of Psychological Type.

Myers, I., M. McCaulley, N. Quenk, and A. Hammer. 1998. Manual: A Guide to the Development and Use of the Myers-Briggs Type Indicator. Palo Alto, Cal.: Consulting Psychologists Press.

Provost, J., and S. Anchors, eds. 1987. Applications of the Myers-Briggs Type Indicator in Higher Education. Palo Alto, Cal.: Consulting Psychologists Press.

Rudd, R., M. Baker, and T. Hoover. 1998. Students and faculty learning styles within academic units in the University of Florida's College of Agriculture. NACTA J. 42(3): 18-24.

Smith, R. 1982. Learning How to Learn: Applied Theory for Adults. New York, N.Y.: Cambridge Press.

Witkin, H. 1976. Cognitive style in academic performance and in teacher-student relations. In Individuality in Learning, 38-72. S. Messick, ed. San Francisco, Cal.: Jossey Bass.

Witkin, H., P. Oltman, E. Raskin, and S. Karp. 1971. Group Embedded Figures Manual. Palo Alto, Cal.: Consulting Psychologists Press. 